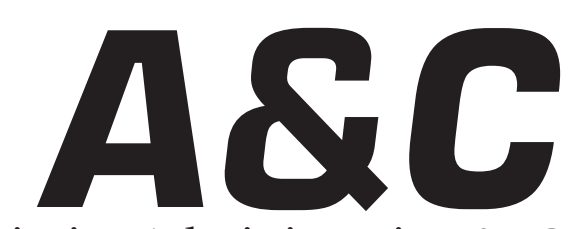

Revista de Direito Administrativo \& Constitucional

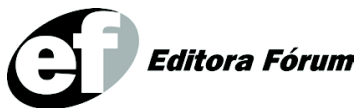

ISSN 1516-3210

A\&C R. de Dir. Administrativo e Constitucional Belo Horizonte ano 8 n. 31 p. 1-272 jan./mar. 2008 


\section{A\&C - REVISTA DE DIREITO ADMINISTRATIVO E CONSTITUCIONAL}

IPDA

Instituto Paranaense

de Direito Administrativo

Direção Geral

Romeu Felipe Bacellar Filho

Direção Editorial

Paulo Roberto Ferreira Motta

Direção Executiva

Emerson Gabardo

Conselho de Redação

Edgar Chiuratto Guimarães

Adriana da Costa Ricardo Schier

Célio Heitor Guimarães

\section{Conselho Editorial}

Adilson Abreu Dallari

Alice Gonzáles Borges

Carlos Ari Sundfeld

Carlos Ayres Britto

Carlos Delpiazzo

Cármen Lúcia Antunes Rocha

Celso Antônio Bandeira de Mello

Clèmerson Merlin Clève

Clóvis Beznos

Enrique Silva Cimma

Eros Roberto Grau

Fabrício Motta

Guilhermo Andrés Muñoz (in memoriam)

Jaime Rodríguez-Arana Muñoz

Jorge Luís Salomoni

José Carlos Abraão
José Eduardo Martins Cardoso
José Luís Said
José Mario Serrate Paz
Juan Pablo Cajarville Peruffo
Juarez Freitas
Julio Rodolfo Comadira
Luís Enrique Chase Plate
Lúcia Valle Figueiredo
Manoel de Oliveira Franco Sobrinho
(in memoriam)
Marçal Justen Filho
Marcelo Figueiredo
Márcio Cammarosano
Maria Cristina Cesar de Oliveira

Nelson Figueiredo

Odilon Borges Junior

Pascual Caiella

Paulo Eduardo Garrido Modesto

Paulo Henrique Blasi

Paulo Neves de Carvalho (in memoriam)

Paulo Ricardo Schier

Pedro Paulo de Almeida Dutra

Regina Maria Macedo Nery Ferrari

Rogério Gesta Leal

Rolando Pantoja Bauzá

Sérgio Ferraz

Valmir Pontes Filho

Yara Stropa

Weida Zancaner

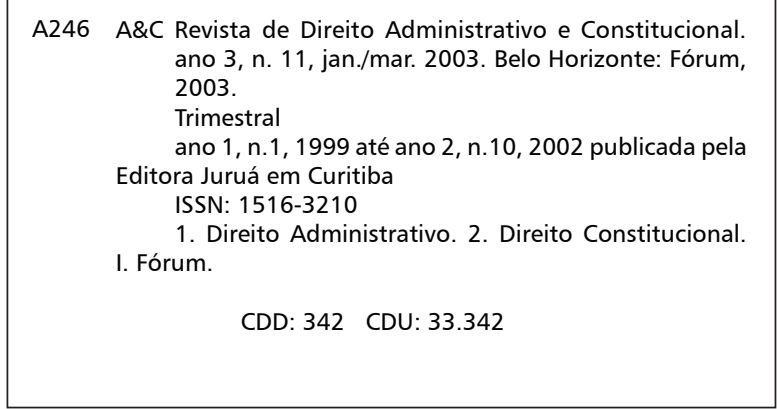

(c) Editora Fórum Ltda. 2008

Todos os direitos reservados. É proibida a reprodução total ou parcial, de qualquer forma ou por qualquer meio eletrônico ou mecânico, inclusive através de processos xerográficos, de fotocópias ou de gravação, sem permissão por escrito do possuidor dos direitos de cópias (Lei $n^{\circ}$ 9.610, de 19.02.1998).

Editora Fórum Ltda.

CEP 30130-007 - Belo Horizonte/MG - Brasil

Tel.: 08007043737

Internet: www.editoraforum.com.br

e-mail: editoraforum@editoraforum.com.br
Av. Afonso Pena, 2770 - 15\%/16 andar - Funcionários

Editor responsável: Luís Cláudio Rodrigues Ferreira

Coordenação editorial: Olga M. A. Sousa

Projeto gráfico e diagramação: Luis Alberto Pimenta

Revisoras: Carolina Rocha

Lourdes Nascimento

Pesquisa jurídica: Fátima Ribeiro - OAB/MG 74868

Bibliotecárias: Fernanda de Paula Moreira

Leila Aparecida Anastácio - CRB 2513 - 6ª região

Os conceitos e opiniões expressas nos trabalhos assinados são de responsabilidade exclusiva de seus autores.

Impressa no Brasil / Printed in Brazil

Distribuída em todo o Território Nacional 


\title{
El Sistema Judicialista Americano: Sus Raíces Hispánicas
}

\author{
Juan Carlos Cassagne \\ Profesor de derecho administrativo en la Universidad de Buenos Aires (UBA) y en la Pontificia Uni- \\ versidad Católica Argentina (UCA). Es Secretario de la Academia Nacional de Derecho de Buenos \\ Aires y miembro de la Real Academia de Ciencias Morales y Políticas de Madrid. Vicepresidente \\ de la Asociación Iberoamericana de Estudios de Regulación (ASIER).
}

Palabras clave: Sistema judicialista americano. Derecho público americano. Constitución de Cádiz. Derecho español.

Índice: I El final de un mito secular sobre las concepciones del derecho público americano - II El influjo del antiguo derecho español y de la neoescolástica - 1 La Constitución de Cádiz de 1812 - 2 Las Fundamental Orders se inspiraron en la neoescolástica - 3 La clave para descifrar la filosofía política de la Constitución gaditana - III El concepto de ley fundamental recogido en la Constitución de Cádiz: su proyección en Iberoamérica - IV La Constitución de Cádiz y la fuente hispánica de otras instituciones fundamentales del derecho iberoamericano y europeo - V La interdicción del ejercicio de funciones judiciales por parte del Ejecutivo. Su fuente en la Constitución de Cádiz de 1812 - VI Principales diferencias entre el sistema judicialista de iberoamérica y el modelo norteamericano - VII A modo de conclusión: el hilo conductor del sistema judicialista en el modelo norteamericano.

\section{El final de un mito secular sobre las concepciones del derecho público americano}

El desarrollo que se ha venido efectuando en el curso de los últimos siglos acerca de los orígenes de las concepciones de derecho público americano comienza a mostrar serias fisuras que lo tornan hoy día insostenible restándole credibilidad.

Esa credibilidad se apoyaba en verdaderos argumentos ad hominen desprovistos de toda comprobación histórica que les sirvieran de apoyatura.

Dicho movimiento - para denominarlo de algún modo-que ignoraba la cronología y trascendencia de las concepciones filosófico-políticas y de los sistemas que imperaron en el mundo, se empeñó en sostener durante mucho tiempo una idea falsa como es la de propugnar que el modelo constitucional americano (particularmente las libertades) tiene sus raíces en instituciones anglo-sajonas, de un modo casi exclusivo y determinante.

Pero el tiempo, con ayuda de la investigación objetiva, se encarga, muchas veces, de corregir los errores históricos y al sacar a la luz la verdad, obedece a un mandato que se encuentra implícito siempre en el seno de 
la sociedad o de la comunidad científica.

Y en este tiempo histórico asistimos a la última etapa de un mito que - sin verdaderos fundamentos - se venía repitiendo acerca de los orígenes de las principales concepciones del derecho público americano en que se asienta la forma democrática, la separación de poderes y, sobre todo, el principio judicialista, cuyas raíces hispánicas no han recibido aún el reconocimiento generalizado de parte de los juristas.

\section{El influjo del antiguo derecho español y de la neoescolástica 1 La Constitución de Cádiz de 1812}

La influencia del antiguo derecho español y de los principios de la neoescolástica en la Constitución liberal de Cádiz de 1812 reviste particular trascendencia en el derecho constitucional de los países de Hispanoamérica, habida cuenta de que es una de sus fuentes nutricias de mayor significación cualitativa y cuantitativa.

Si bien fue, en su momento, una cuestión debatida, no puede dudarse ahora, a la luz de los estudios e investigaciones históricas, que la Constitución Política de la Monarquía Española, promulgada en Cádiz el 19 de marzo de 1812, "fue un bosquejo bien concebido para una sociedad hispana moderna", ${ }^{1}$ que representó una concepción política que hunde sus raíces en el antiguo derecho español antes que en la revolución francesa y, sobre todo, en el pensamiento político de la neoescolástica salmantina.

Ante todo, hay que advertir que lo que algunos denominan quiebre con el antiguo régimen importa la ruptura de la Carta de Cádiz con los principios propios del absolutismo borbónico e incluso inglés (desde luego que con anterioridad a la Glorius Revolution de 1688). En ese sentido, la expresión antiguo régimen, al menos en España, ha de utilizarse con sumo cuidado ya que toda la tradición política española anterior al advenimiento del absolutismo borbónico (incluso al régimen de los Austrias) era favorable a las libertades y a la limitación de los poderes siguiendo una línea contraria a las concepciones que sostenían el origen divino del poder real y su principal consecuencia reflejada en el principio autocrático, surgidas y desarrolladas, principalmente, por la dinastía de los borbones en Francia.

En el marco de esa tradición política que se remonta al "Fuero Juzgo" y a las Cortes y Fueros de Aragón, Castilla y Navarra, se desarrollaron

RODRíGUEZ, Mario, El experimento de Cádiz en Centroamérica, 1808-1826, Fondo de Cultura Económica, México, 1984, p. 131.

A \& C R. de Dir. Administrativo \& Constitucional, Belo Horizonte, ano 8, n. 31, p. 69-89, jan./mar. 2008 
numerosas instituciones que más tarde se incorporaron en las cartas constitucionales americanas así como en algunas europeas.

Como se ha dicho "ni Francia ni Inglaterra tuvieron instituciones similares ni, por supuesto, las tuvieron en el siglo XVII", ${ }^{2}$ siendo justo reconocer que las sucesivas doctrinas adversas al principio autocrático (que era algo así como el eje de la Monarquía de origen divino) provinieron de

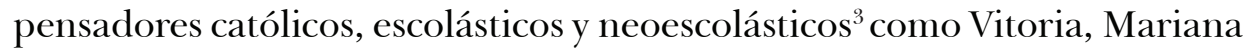
y Suárez, entre otros, pertenecientes a la escuela de Salamanca. Así, el primero de los autores citados, al distinguir entre causa mediata, inmediata y directa del poder llega a sostener que la fuente directa se encuentra en el pueblo o en la comunidad política.

\section{Las Fundamental Orders se inspiraron en la neoescolástica}

La evolución posterior muestra también cómo las concepciones políticas y principios jurídicos fundamentales del antiguo derecho hispánico influyeron en las Fundamental Orders de la colonia de Connecticut de 1639, considerada como la primera expresión de los principios liberales y republicanos que se plasmaron luego en las Constituciones de las demás colonias y distintos Estados, cuya recepción culminó en la Constitución de $1787 .{ }^{4}$

Contrariamente a lo que algunos llegaron a suponer, Locke (que por otra parte no se encuentra citado en "El Federalista" de Hamilton y que sólo tenía seis años cuando se sancionaron las Fundamental Orders), no pudo haber sido el inspirador de la concepción política que las anima, atribuyéndose su paternidad al escolástico puritano Richard Hooker, cuya influencia sobre la obra de Locke ha sido puesta de relieve por autorizada doctrina de nuestros iuspublicistas. ${ }^{5}$

El sentido del proceso que transportó las ideas fue, pues, inverso al que se predicó durante los últimos siglos por algunos sectores, quizás de buena fe pero con un franco desconocimiento sobre la génesis histórica de las concepciones políticas y filosóficas. No deja de sorprender que pensadores argentinos hayan hecho trascendentes aportes para desentrañar la

\footnotetext{
STEVERLINCK GONNET, Joris, La Universidad de Salamanca y la Constitución de los Estados Unidos, UCA, Buenos Aires, 2003, p. 122.

3 Ampliar en RODRíGUEZ VARELA, Alberto, "La neoescolástica y las raíces del constitucionalismo", Separata de la Academia Nacional de Ciencias Morales y Políticas de Buenos Aires, Buenos Aires, 2005, especialmente p. 234 y ss.

4 Vid. STEVERLINCK GONNET, Joris, op. cit., p. 155 y ss.

5 Cfr. RODRÍGUEZ VARELA, Alberto, op. cit., p. 270.
} 
verdad histórica tejida alrededor de este punto capital del pensamiento político del constitucionalismo clásico, llegando a la conclusión que la fuente de gran parte de las ideas políticas y filosóficas de la Constitución norteamericana se hallan en concepciones provenientes de la escolástica o neoescolástica salmantina.

Esta tesis es algo más que una idea o inferencia. En efecto, mientras los protestantes, calvinistas, anglicanos y puritanos, según sus diferentes concepciones, defendían el origen divino del poder, la principal escuela científica organizada que sustentaba la tesis contraria era, en esa época histórica, la Escuela de Salamanca, a través de la neoescolástica.

A veces, es difícil descubrir el rastro de las ideas en la historia de las instituciones. Pero en este caso, resulta casi increíble que haya ocurrido lo contrario, aunque sorprende que los europeos (hasta los propios españoles) y los norteamericanos hayan tardado tanto tiempo en enterarse de la genealogía de muchas de las principales instituciones políticas del mundo occidental y de la filosofía que las nutre.

De acuerdo con esta tesis, la línea que adopta la filosofía política del derecho constitucional norteamericano, que representa la concepción que sostiene que el poder no tiene origen divino sino que encuentra su causa directa en el consentimiento del pueblo, se inicia con las Fundamental Orders, inspiradas en la neoescolástica predicada por Richard Hooker. Al revés de la trama que postularon algunos pensadores, estas ideas fueron adoptadas luego por John Locke quien, a su vez, influenció a Montesquieu y de alguna manera también (aunque en forma parcial) a la concepción francesa de la soberanía del pueblo.

Y como las ideas continúan circulando, no debe llamar la atención el hecho que la concepción de Montesquieu (aunque no tuvo una influencia en los debates de la Convención de Filadelfia ${ }^{6}$ terminase siendo la justificación teórica de esa doctrina en "El Federalista" de Hamilton, cerrándose, de ese modo, una suerte de vínculos de interdependencia entre quienes articulan unas concepciones que implicaron el desarrollo de las bases filosóficas y políticas sentadas por la neoescolástica.

\section{La clave para descifrar la filosofía política de la Constitución gaditana}

\footnotetext{
6 Cfr. BOSCH, Jorge Tristán, Ensayo de interpretación de la doctrina de la separación de los poderes, Universidad de Buenos Aires, Buenos Aires, 1944, p. 150.
}

A \& C R. de Dir. Administrativo \& Constitucional, Belo Horizonte, ano 8, n. 31, p. 69-89, jan./mar. 2008 
Nos parece que en los principios de la escuela salmantina se encuentra la clave para descifrar la filiación política de la Constitución de Cádiz de 1812, según se desprende de la fundamentación teórica que exhibe el Discurso Preliminar atribuido a Agustín Arguelles, fino y agudo jurista español cuyo talento y conocimientos histórico-jurídicos demostró sobradamente en el curso de los debates en el seno de las Cortes generales y extraordinarias.

Asdrúbal Aguiar ha podido advertir también, desde una óptica más liberal, la singularidad de la realidad política, histórica, cultural y religiosa de España, que impedía transplantar las concepciones de los filósofos franceses de la Ilustración. ${ }^{7}$

Veamos, a modo de síntesis, algunas de las premisas políticas fundamentales:

(a) el principio de que la soberanía reside en la Nación $\left(\text { art. } 3^{\circ}\right)^{8}$ y el carácter electivo de la representación legislativa junto al reconocimiento de que la potestad legislativa reside en las Cortes, aunque con intervención del Rey (art. 15), configurándose lo que el Discurso Preliminar califica como una monarquía moderada;

(b) la clara recepción de la doctrina de la separación de poderes, ${ }^{9}$ nítidamente opuesta a la concepción absolutista del poder, estableciendo atribuciones definidas y limitadas para mantener el equilibrio entre los órganos fundamentales del Estado;

(c) la adopción del sistema judicialista puro, prescribiendo la expresa interdicción al ejercicio de funciones judiciales por parte de las Cortes y

\footnotetext{
AGUIAR ARANGUREN, Asdrúbal, "La libertad de imprenta en las Cortes de Cádiz: relectura desde la Revolución Francesa", en la obra colectiva La Constitución de Cádiz de 1812, Universidad Católica Andrés Bello, Caracas, 2004, p. 149, anota que "Jovellanos, hombre que sería muy influyente en el ideario de las Cortes de Cádiz, lector asiduo de los filósofos franceses y de los economistas ingleses, sabe bien que las doctrinas de éstos no pueden trasplantarse, sin más, a la realidad española. Se preocupaba, antes bien, por la ignorancia hispana de su propia tradición y, de manera particular, por la falta de estudios y de libros acerca del derecho público propio; quejándose, incluso, de las innecesarias desviaciones en que había incurrido: así las Partidas de Alfonso XI El Sabio, abrazando sin discresión máximas y principios de la escuela italiana que bien pudo encontrar en su más antigua 'constitución'. Apuntaba Jovellanos, de modo puntual, al carácter específico de la monarquía peninsular y que, en su juicio, a diferencia de las experiencias despóticas o absolutistas conocidas en otras partes de Europa, fraguó desde los períodos visigóticos, asturiano y castellano dentro de un sistema de frenos impuestos por los Concilios, primero, y luego por las Cortes".

8 ROMANO, Andrea: "L'influenza della Carta gaditana nel constitucionalismo italiano ed europeo", en la obra colectiva La Constitución de Cádiz de 1812, cit., p. 352, destaca que los diputados declararon, apenas constituidas las Cortes, que representaban a la Nación española y que en ellas residía la soberanía nacional.

9 Cfr. "Discurso Preliminar", en Constitución Política de la Monarquía Española, promulgada en Cádiz, a 19 mar. 1812, con prólogo de Eduardo García de Enterría, Civitas, Madrid, 1999, p. 22, en el que señala que "La experiencia de todos los siglos ha demostrado hasta la evidencia que no puede haber libertad ni seguridad en un estado en donde el ejercicio de toda la autoridad esté reunido en una sola mano".
} 
el Rey (art. 243).

\section{El concepto de ley fundamental recogido en la Constitución de}

\section{Cádiz: su proyección en Iberoamérica}

En Iberoamérica se utilizó, como es sabido, el concepto de ley fundamental ${ }^{10}$ de una manera similar al que recoge el Discurso Preliminar de la Constitución de Cádiz de 1812. Allí se alude a "un sistema de ley fundamental y constitutiva, en el que estuviese contenido con enlace, armonía y concordancia cuanto tienen dispuesto las leyes, fundamentales de Aragón, de Navarra y de Castilla," ${ }^{11}$ declarando que sus autores están penetrados más de su "índole y espíritu" que del tenor literal de las leyes fundamentales. ${ }^{12}$

Esa misma idea de la Constitución histórica o si se quiere internava ${ }^{13}$ a ser desplazada más tarde durante el siglo XX por la concepción formal de la Constitución (que prevalece a partir de Kelsen y del positivismo constitucional) que encuentra sólo en la norma la fuente de todo el derecho hasta confundirse con él. Esto acarrea el desplazamiento de la distinción entre ley y derecho o justicia, lo cual significa que toda norma positiva se supone verdadera y justa por el hecho de haber sido sancionada conforme el procedimiento legal e impide dar cabida dentro del sistema constitucional y administrativo, a los principios generales del derecho, borrando su diferenciación con las normas.

Sin embargo, ha terminado prevaleciendo la distinción entre normas y principios (llámense éstos estándares o directivas) provocando el quiebre radical del positivismo. Ello impide también generalizar la concepción de la Constitución como norma, habida cuenta que revistiendo aquella la condición de suprema resulta ser, al propio tiempo, solo una parte de la ley fundamental, la que se encuentra concebida como un complejo compuesto tanto por valores y principios integrados con elementos históricos y reales, como por normas (en el sentido de fórmulas preceptivas que definen el deber ser).

Por esta razón, hay que tener cuidado en no confundir el valor nor-

\footnotetext{
10 En el texto del Acuerdo de San Nicolás de los Arroyos se declara que "siendo una ley fundamental de la República Argentina el Tratado celebrado el 4 de enero de 1831 entre las Provincias de Buenos Aires, Santa Fe y Entre Ríos, por haberse adherido a él todas las demás Provincias de la Confederación, será religiosamente observado en todas sus cláusulas..." (Cláusula 1º). Más tarde, al sancionarse la Constitución de 1853 ésta hace referencia a esa ley fundamental en el Preámbulo resaltando que ésta se sanciona "en cumplimiento de pactos preexistentes", en clara alusión a dicho Pacto Federal.

11 Cfr. Constitución Política de la Monarquía Española..., cit., p. 2.

12 Cfr. Constitución Política de la Monarquía Española..., cit., p. 20.

13 MUÑOZ MACHADO, Santiago, Constitución, lustel, Madrid, 2004, ps. 32-33.
} 
mativo de una constitución como fuente del derecho con el principio de supremacía (consagrado en el art. 31 de la Constitución Argentina y en el Artículo VI de la norteamericana) ya que esta última característica se deriva, además de las normas positivas, de los principios generales contenidos en el Preámbulo, en las declaraciones de derechos y sin perjuicio de que también surgen de los usos y costumbres constitucionales que, para Hauriou, conforman una suerte de "superlegalidad" constitucional.

Esta peculiar complexión de la constitución histórica-normativa, con principios pétreos, ${ }^{14}$ hace que no todos los tratados puedan ser superiores a las leyes, pues como lo prescribe el art. 27 de la Constitución Argentina, ellos deben ser compatibles con los principios de derecho público establecidos en la Constitución y aun por encima de ella, o que surgen de su propia naturaleza, como la división de poderes.

\section{La Constitución de Cádiz y la fuente hispánica de otras institu- ciones fundamentales del derecho iberoamericano y europeo}

Del propio Discurso Preliminar se desprende el origen hispánico de muchos principios e instituciones del derecho público iberoamericano y europeo, nacidos con anterioridad al derecho anglosajón, bastante poco desarrollado en la época medieval. Pero no sólo se trata de la opinión de Arguelles sino que ello ha sido sostenido también por autores ingleses, europeos continentales y argentinos. ${ }^{15}$

Las Cortes de Cádiz de 1812 fueron, sin duda, un escenario único e irrepetible, para la recopilación positiva de esos principios, no obstante lo cual, quizás por considerarlos parte del concepto de ley fundamental, ellos no tuvieron recepción expresa en el texto de la Constitución. En su seno, la labor de los constituyentes americanos, ${ }^{16}$ aunque menores en número a los peninsulares, ${ }^{17}$ no fue menos trascendente pues, en definitiva, se prescribió la ciudadanía española para los nacidos en ambos hemisferios ${ }^{18}$ como integrantes todos de una única España, derogándose el sistema del régimen absolutista anterior (aun cuando se mantuvo el centralismo borbónico, mal visto por los españoles americanos) estableciéndose el modelo

14 Véase: BIDART CAMPOS, Germán J., Derecho Constitucional, To I, Ediar, Buenos Aires, 1964, p. 118.

15 Cfr. LINARES QUINTANA, Segundo V., "Raíces hispánicas del constitucionalismo", Separata de la Academia Nacional de Ciencias Morales y Políticas, Buenos Aires, 2001, p. 9, especialmente, p. 12 y ss. y sus citas.

16 Al respecto puede verse: DEL VALLE IBERLUCEA, Enrique, "Los diputados de Buenos Aires en las Cortes de 1810", Anales de la Facultad de Derecho y Ciencias Sociales, To Segundo, Segunda Serie, Coni Hermanos, Buenos Aires, 1912, p. 382 y ss.

17 Según Solís, los diputados que asistieron a las Cortes de Cádiz fueron 63, es decir, el 21\% del total, habiendo ejercido diez de ellos la Presidencia. Luego de destacar la importancia de su actuación en la defensa de los 
de libertad económica extensivo a los habitantes del territorio americano y los del territorio español, como límite al poder político-administrativo. ${ }^{19}$

Tenemos la impresión que el análisis jurídico de las fuentes del derecho hispánico, especialmente la armonización de los estudios llevados a cabo por los historiadores del derecho o los realizados en el campo de la dogmática administrativa y constitucional, no ha sido aun efectuada de una manera orgánica. Como se verá, de la sola cita de las instituciones que pasamos a mencionar, se desprende la necesidad de amalgamar al menos dos de los clásicos y principales enfoques doctrinarios (el histórico y el dogmático).

Por de pronto, la Constitución gaditana, votada tanto por liberales agnósticos como por los sectores liberales y absolutistas que profesaban la religión católica, comienza por reconocer a Dios como autor y legislador supremo de la sociedad. ${ }^{20}$ Esta expresión que luce en el Preámbulo de Cádiz, a diferencia de la Constitución norteamericana, resulta opuesta a la concepción absolutista francesa de la época borbónica que propugnaba la tesis del origen divino de la monarquía, a la cual se opusieron, como es sabido, las tesis de Suárez y de Mariana, entre otros. ${ }^{21}$

En efecto, por poco rigor científico con que se examine la doctrina de la Constitución de Cádiz sobre el origen de la monarquía se advierte que ella proclama que el monarca es "Rey de las Españas" por la Constitución, cuyas Cortes generales y extraordinarias, sin distinción de estamentos ni de clases, representaban la unidad del pueblo español de ambos hemisferios.

De ese modo, desde una perspectiva histórica, la Constitución gaditana, aunque tardíamente, ${ }^{22}$ vino a reinsertar las instituciones en su matriz histórica al enmarcarse en el espíritu de las antiguas leyes fundamentales de la monarquía, limitando el poder de ésta y estableciendo el principio de división de poderes como sistema básico de la nueva organización polí-

intereses americanos coincidente con la opinión de Arguelles (Cfr. SOLís, Ramón, El Cádiz de las Cortes, Silex, Madrid, 1987, p. 362).

${ }^{18}$ Art. 18 de la Constitución de Cádiz.

${ }^{19}$ GONZÁLEZ SALINAS, Jesús, La Constitución de Cádiz: su modelo económico-administrativo, Universidad de Cádiz, Servicio de Publicaciones, Cádiz, 1994, Cap. III.

${ }^{20}$ Una idea semejante se halla en el Preámbulo de la Constitución Argentina de 1853 (actualmente en vigencia en esta parte) cuyos constituyentes (es decir, los representantes del pueblo) invocan la protección de Dios proclamando que es "fuente de toda razón y justicia".

${ }^{21}$ Ampliar en RODRÍGUEZ VARELA, Alberto, "La neoescolástica y las raíces del constitucionalismo", cit., p. 7 y ss., esp. ps. 14-26.

A \& C R. de Dir. Administrativo \& Constitucional, Belo Horizonte, ano 8, n. 31, p. 69-89, jan./mar. 2008 
tica instituida. ${ }^{23}$ Entre otras cosas, prescribe, enfáticamente, que España "no es ni puede ser patrimonio de ninguna familia ni persona" (en obvia alusión al monarca y su familia) y si bien se conservan resabios absolutistas en materia religiosa (como el art. 12 que prohíbe el ejercicio de cualquier otra religión que la católica) lo cierto es que se declara el deber de la Nación de proteger las libertades civiles, la propiedad y los demás derechos de las personas (art. 13).

El balance final de la Constitución de Cádiz, pese a la crítica que ha recibido de distintos sectores del pensamiento jurídico e histórico español, resulta favorable al equilibrio de poderes y, consecuentemente, a las libertades de los ciudadanos. Su limitada vigencia (al ser abrogada por Fernando VII en 1814) en el territorio peninsular no empece a que su proyección en la América española haya sido realmente extraordinaria, influenciando, de un modo directo o indirecto, todos los ordenamientos constitucionales de nuestras jóvenes repúblicas.

Pero lo que realmente asombra a cualquier estudioso de las instituciones del derecho hispanoamericano (también debería asombrar a quienes consideran que, en general, éste es un producto totalmente derivado de las concepciones de la Revolución Francesa) es el hecho de que trascendentes conquistas del derecho público occidental moderno encuentran su origen no tanto en la Carta Magna, en Locke o en Montesquieu (y menos en las ideas de los jacobinos o girondinos) sino en el antiguo derecho español (anterior al absolutismo) y en la filosofía política de la neoescolástica de la llamada escuela de Salamanca.

Al frente de ese catálogo de garantías y de derechos se encuentra la institución del Justicia de Aragón, funcionario independiente encargado de dirimir las controversias, entre otros casos, en que eran parte el Rey y los caballeros y, posteriormente, los habitantes de las ciudades (la burguesía). Y aunque no haya precisión en cuanto a la fecha en que se instauró la figura (desaparecida tras la muerte de Juan de Lanuza en 1591, bajo el reinado de Felipe II) lo cierto es que su prestigio traspasó las fronteras españolas muchos siglos después ya que esa denominación (“Justice"

\footnotetext{
22 Se ha dicho que fue un intento fracasado de llevar la paz a América: PÉREZ GUILHOU, Dardo, La opinión pública española y las Cortes de Cádiz frente a la emancipación americana, Academia Nacional de la Historia, Buenos Aires, 1981, p. 192.

${ }^{23}$ Cfr. FERNÁNDEZ TORRES, Juan Ramón, La formación histórica de la jurisdicción contencioso administrativa (1845-1868), Civitas, Madrid, 1998, p. 93, afirma que la Constitución de Cádiz supone la "sujeción del poder del Rey al imperio de las leyes".
} 
y no "Judge") es la que han tenido, y actualmente tienen, los jueces de la Suprema Corte de los Estados Unidos.

Porque en el derecho español previo al proceso constitucionalista, con las consabidas limitaciones de las diferentes épocas históricas, hay que trazar una raya bastante ancha entre el sistema del absolutismo (sobre todo a partir de la dinastía borbónica) y el derecho del antiguo régimen español (de Aragón, Castilla y Navarra) que, siendo favorable a las libertades y estando más próximo a la división de poderes, fue configurando su verdadera ley fundamental, en el sentido antes explicado (que recoge el Discurso Preliminar de la Constitución de Cádiz), con anterioridad a las concepciones que animaron la Revolución Francesa, las cuales recién comenzaron a abrirse paso por el mundo tras las conquistas militares de los ejércitos napoleónicos.

En efecto, entre las instituciones más arraigadas en ese antiguo derecho español, aparte de una concepción embrionaria de la división de poderes, ${ }^{24}$ se encuentran desde las variadas hipótesis el derecho de resistencia a la opresión (Vitoria), ${ }^{25}$ la declaración de nulidad ipso foro, ${ }^{26} \mathrm{el}$ principio de legalidad e igualdad en materia tributaria, ${ }^{27}$ hasta nada menos que el juicio o recurso de manifestación que, según los antecedentes y estudios realizados ${ }^{28}$ equivale al habeas corpus del derecho anglosajón; ${ }^{29}$ y se instituyó con anterioridad al nacimiento de dicha institución en Inglaterra. Otro antecedente está representado por la categoría misma de "ciudadano", que aparece en los derechos de Aragón, Castilla y Navarra. En fin, ese bagaje institucional demuestra que siglos de absolutismo no pueden borrar la historia ni el hecho de que la cultura jurídica de los pueblos españoles (en general toda su cultura), durante la edad media, haya sido superior a la existente en Inglaterra.

A ello se añade un paradigma que destaca el Discurso Preliminar vinculado con el moderno principio de la tutela judicial efectiva el cual,

\footnotetext{
${ }^{24}$ Sobre la influencia de la neoescolástica en Locke y en la división de poderes, RODRIGUEZ VARELA, Alberto, op. cit., p. 30 y ss. En los fueros de Aragón, véase: LINARES QUINTANA, Segundo V., op. cit., p. 17.

25 RODRIGUEZ VARELA, Alberto, op. cit., p. 12.

26 Significa que ella surge del propio foro cumpliendo una función similar a la violación de derechos y garantías constitucionales por arbitrariedad o ilegalidad manifiesta, cuya formulación se encuentra en la regulación de los procesos de amparo de los países iberoamericanos (v.g. Argentina y México).

27 Cuyos orígenes se remontan a los ordenamientos de Castilla y Aragón; véase: Constitución Política de la Monarquía Española..., cit., p. 12.

${ }^{28}$ LINARES QUINTANA, Segundo V., op. cit., p. 23 y ss.

${ }^{29}$ Cfr. GARCÍA DE ENTERRÍA, Eduardo - FERNÁNDEZ, Tomás Ramón, Curso de Derecho Administrativo, T II, 6 ed., Civitas, Madrid, 1999, ps. 66-67.
} 
aunque sin las actuales proyecciones, fue también enunciado por Arguelles en los siguientes términos: "La justicia, Señor, ha de ser efectiva y para ello su curso ha de estar expedito," ${ }^{30}$ habiendo dicho antes que "uno de los principales objetos de la Constitución es fijar las bases de la potestad judicial, para que la administración de justicia sea en todos los casos efectiva, pronta e imparcial." ${ }^{11}$

En rigor, no se puede desconocer que, antes del advenimiento del absolutismo, se perfilaron en España, las raíces de numerosos principios y técnicas de derecho público, aparte de los mencionados, tales como el carácter electivo del monarca (como actualmente se encuentra regulado el órgano Ejecutivo en las repúblicas iberoamericanas), la responsabilidad de los jueces, la autonomía de los gobiernos de las ciudades, el juicio de residencia y el privilegio de unión, ${ }^{32}$ que era un derecho y un procedimiento para destituir al Rey que no difiere mucho del llamado actualmente "juicio político", regulado en las constituciones de Latinoamérica, merced al cual el Congreso puede destituir al Presidente de la República.

\section{La interdicción del ejercicio de funciones judiciales por parte del Ejecutivo. Su fuente en la Constitución de Cádiz de 1812}

Lo primero que salta a la vista es la circunstancia que muestra que el derecho constitucional de casi todos los países de iberoamérica ha adoptado el sistema judicialista, tanto para la justicia ordinaria de tipo civil, comercial o penal como para el juzgamiento de los actos de la Administración Pública y otros órganos del Estado (contencioso administrativo). La excepción a esta regla generalizada ha sido Colombia, que implantó la justicia administrativa sobre la base del modelo francés y la consecuente institución de un Consejo de Estado. ${ }^{33}$

En lo que concierne al juzgamiento de los actos y contratos de la Administración Pública hay que advertir que el sistema judicialista admite tanto el modelo de unidad de jurisdicción (con excepciones fundadas en razones de especialidad o históricas) o bien, el basado en la dualidad o pluralidad de jurisdicciones. ${ }^{34}$

${ }^{30}$ Constitución Política de la Monarquía Española..., cit., p. 65.

31 Constitución Política de la Monarquía Española..., cit., p. 57.

32 Recuerda Arguelles en el Discurso Preliminar que "además de la reunión periódica y frecuente de las Cortes, tenían los aragoneses el privilegio de la unión, institución tan singular, que ninguna otra nación conocida ofrece ejemplo de esta naturaleza. Su objeto era oponerse abiertamente a la usurpación que hacía el Rey o sus Ministros de los fueros o libertades del reino, hasta poderlo destronar y elegir otro en su lugar...". (Cfr. Constitución Política de la Monarquía Española..., cit., p. 12).

33 Constitución Política de Colombia. Art. 116: "La Corte Constitucional, la Corte Suprema de Justicia, el Consejo de Estado, el Consejo Superior de la Judicatura, la Fiscalía General de la Nación, los Tribunales y los Jueces, 
Con algunas variantes poco significativas, los sistemas latinoamericanos - en lo que atañe al llamado contencioso-administrativo - han terminado coincidiendo con la versión actual española pues si bien algunos de ellos se declararon, en su momento, tributarios del constitucionalismo norteamericano como Venezuela ${ }^{35} \mathrm{y}$ Brasil, ${ }^{36}$ lo cierto es que han terminado, en la evolución operada en sus principales instituciones, aproximándose más al modelo español actual y a los principios que lo rigen que al vigente en los Estados Unidos.

Ello no implica desconocer que, en muchos casos, las constituciones de Latinoamérica han recibido la impronta de la influencia del sistema norteamericano en punto a la forma federal de gobierno y a la organización del Poder Judicial, principalmente en lo que atañe a la articulación de la competencia del fuero federal en razón de las personas o de la materia. ${ }^{37}$

Sin embargo, esa influencia, con ser importante, no amengua la trascendencia de un principio capital el cual, extrañamente, recién comenzó a aplicarse en su país de origen, casi un siglo después. Al no hallarse contemplado en la Constitución norteamericana ello ha determinado que, en definitiva, los sistemas judicialistas iberoamericanos hayan transitado por andariveles diferentes y terminando de configurar, de últimas, un sistema adaptado más a la idiosincrasia de cada pueblo y sus realidades históricas que al punto de partida común, también opuesto al modelo francés.

Ese principio capital del derecho público iberoamericano, derivado de la interpretación más pura y ortodoxa de la división de poderes, se halla en la médula del constitucionalismo hispánico de raíz liberal, ${ }^{38}$ conteniéndose

administran Justicia. También lo hace la Justicia Penal Militar..." Art. 237: "Son atribuciones del Consejo de Estado: 1. Desempeñar las funciones de tribunal supremo de lo contencioso administrativo, conforme a las reglas que señale la ley..." Art. 238: "La jurisdicción de lo contencioso administrativo podrá suspender provisionalmente, por los motivos y con los requisitos que establezca la ley, los efectos de los actos administrativos que sean susceptibles de impugnación por vía judicial".

34 GONZÁLEZ PÉREZ, Jesús, Comentarios a la ley de la jurisdicción contencioso administrativa, To I, 4 ed., Civitas, Madrid, 2003, p. 92.

35 Constitución de Venezuela. Art. 259: "La jurisdicción contencioso administrativa corresponde al Tribunal Supremo de Justicia y a los demás tribunales que determine la ley. Los órganos de la jurisdicción contencioso administrativa son competentes para anular los actos administrativos generales o individuales contrarios a derecho, incluso por desviación de poder; condenar al pago de sumas de dinero y a la reparación de daños y perjuicio originados en responsabilidad de la Administración; conocer de reclamos por la prestación de servicios públicos; y disponer lo necesario para el restablecimiento de las situaciones jurídicas subjetivas lesionadas por la actividad administrativa".

${ }^{36}$ Constitución de Brasil. Art. 92: "São órgãos do Poder Judiciário: I. o Supremo Tribunal Federal; II. o Superior Tribunal de Justiça; III. os Tribunais Regionais Federais e Juízes Federais; IV. os Tribunais e Juízes do Trabalho; V. os Tribunais e Juízes Eleitorais; VI. os Tribunais e Juízes Militares; VII. os Tribunais e Juízes dos Estados e do Distrito Federal e Territórios". Art. 102: "Compete ao Supremo Tribunal Federal, precipuamente, a guarda da Constituição, cabendo-Ihe: I. processar e julgar, originariamente: a) a ação direta de inconstitucionalidade de lei ou ato normativo federal ou estadual e a ação declaratória de constitucionalidade de lei ou ato normativo federal..."

37 Arts. 108,109 y $116 \mathrm{CN}$.

A \& C R. de Dir. Administrativo \& Constitucional, Belo Horizonte, ano 8, n. 31, p. 69-89, jan./mar. 2008 
en el art. 243 de la Constitución de Cádiz de 1812 que prescribe: "Ni las Cortes ni el Rey podrán ejercer en ningún caso las funciones judiciales, avocar causas pendientes, ni mandar a abrir los juicios fenecidos."

Con las modificaciones orgánicas que demandaba la adaptación del precepto al modelo republicano, la Constitución argentina de 1853 reprodujo el mismo principio, ${ }^{39}$ tomándolo, según BOSCH, del art. 108 de la Constitución de Chile de $1833 .{ }^{40}$

De acuerdo con el pensamiento del máximo inspirador doctrinario de la Constitución Argentina, Juan Bautista ALBERDI, expuesto al redactar las Bases y presentar al Congreso el proyecto de texto constitucional que finalmente se sancionó y que recogió la mayor parte de los artículos proyectados, ${ }^{41}$ resulta evidente que esa interdicción tuvo por objeto compensar el peso de un sistema presidencialista fuerte (al que se atribuyó un poder reglamentario de origen monárquico) con relación a los otros poderes del Estado, principalmente de cara al Poder Judicial. Y no es casual que frente a una situación en la que se jugaba la aplicación del principio de separación de los poderes, ${ }^{42}$ sobre bases semejantes, la fórmula que finalmente se aprobó haya sido la misma en España y en los países de Hispanoamérica que dictaron sus constituciones tiempo después, como la chilena en 1833 y la argentina en 1853.

La fórmula que finalmente adoptó la Constitución Argentina, cuya trascendencia histórica constitucional estriba en el hecho de hallarse plenamente vigente, desde 1853, en su redacción original, dispone que: "Art. 109 CN: En ningún caso el presidente de la Nación puede ejercer funciones judiciales, arrogarse el conocimiento de causas pendientes o restablecer las fenecidas".

Interesa puntualizar que un precepto semejante se hallaba también en el Reglamento Provisorio del 22 de octubre de 1811 de la Junta

\footnotetext{
38 El término liberal tenía en el siglo XIX una connotación más inclinada a definir el movimiento o tendencia que ponía el acento en la defensa de las libertades políticas aunque también propugnaba la libertad económica.

39 Art. 92 de la Constitución de 1853.

40 BOSCH, Jorge T., ¿Tribunales judiciales o tribunales administrativos para juzgar a la Administración Pública?, Victor P. Zavalía, Buenos Aires, 1951, p. 55

41 Cfr., entre otros, MAYER, Jorge M., "La influencia de Alberdi, Gorostiaga, Campillo y Gutierrez en la Constitución de 1853", Separata de la Academia Nacional de Derecho y Ciencias Sociales, n 19, Buenos Aires, 1981, p. 3 y ss.; GARCÍA BELSUNCE, Horacio A., "Homenaje a la Constitución Nacional de 1853 en su sesquicentenario", Anales de la Academia Nacional de Derecho y Ciencias Sociales de Buenos Aires, n. 41, La Ley, Buenos Aires, 2003, p. 7 y ss.

42 Véase: FERNÁNDEZ TORRES, Juan Ramón, La formación histórica de la jurisdicción contencioso administrativa (1845-1868), Civitas, Madrid, 1998, ps. 93-94.
} 
Conservadora ${ }^{43}$ pero nos parece, por demás probable, que el origen del principio provenga del Reglamento preconstitucional ${ }^{44}$ que dictaron las Cortes de Cádiz para el funcionamiento del Consejo de Regencia que es de fecha anterior (16 de enero de 1811).

A este respecto, también es del caso destacar que la concepción que se desliza en el Discurso Preliminar de Arguelles (algo así como la exposición de motivos que fundamenta la Constitución de Cádiz de 1812) es la idea de un poder judicial independiente originado en el derecho aragonés, como efectivamente ha sido recogido por los historiadores del antiguo derecho español. ${ }^{45}$

Así fue como quedó perfilado uno de los grandes preceptos básicos del derecho constitucional iberoamericano que constituye la base de nuestros sistemas judicialistas al prescribirse el principio del "juez natural”, esto es - como reza el Discurso Preliminar — que "nadie pueda ser juzgado por comisiones especiales, sino por el tribunal establecido con anterioridad a la ley", ${ }^{46}$ principio éste que ha sido la fuente indubitable del art. 18 de la Constitución Argentina. ${ }^{47}$

En algunos de los ordenamientos iberoamericanos tal principio aparece contemplado en forma expresa mientras que, en otros, llega a traslucirse o se encuentra implicado, ya sea en forma implícita o por el principio de la especialidad. Efectivamente, un repaso sobre las fuentes constitucionales de los países iberoamericanos revela que el principio

${ }^{43}$ Art. 7 del Reglamento del 22 de octubre de 1811. Interesa señalar que, entre los antecedentes del citado principio, que hace a la separación e independencia del poder judicial, se encuentra -como lo recuerda Luis V. Varela-(véase, VARELA, Luis V., Historia Constitucional de la República Argentina, T I, edición del autor, Taller de Impresiones Oficiales, La Plata, 1910, p. 307), el Reglamento dictado el 25 de mayo de 1810, cuyo punto VII prescribía que los integrantes de la Primera Junta quedaban "excluidos de ejercer el poder judiciario" el cual se refundía "en la Real Audiencia a quien pasarán todas las causas contencioso-administrativas que no sean del gobierno". Sin embargo, este precepto, anterior a la sanción de la Constitución de Cádiz de 1812 y dictado antes que se reunieran las Cortes (Septiembre de 1810) no es la fuente en que abrevó el ex. art. $95 \mathrm{CN}$ (actual art. $109 \mathrm{CN}$ ) como lo señalamos en el texto. En cambio, de la mera comparación entre ambos textos surge que el citado precepto de 1810 se basó en el artículo primero del Capítulo V, sección tercera, de la Constitución francesa de 1791, el cual establecía que "El poder judiciario no puede, en caso alguno, ser ejercido por el cuerpo legislativo ni por el Rey".

${ }^{44}$ Debemos advertir que el mencionado precepto del Reglamento Provisorio no fue una creación vernácula, por cuanto reproduce el principio que figura en el reglamento provisional dictado por las Cortes de Cádiz el 16 de enero de 1811 para reglamentar las atribuciones del Consejo de Regencia (art. 1 del Cap. III).

${ }^{45}$ Este principio de origen hispánico no encuentra símil en el derecho anglosajón. Sus antecedentes se remontan al antiguo derecho aragonés, vid: LÓPEZ DE HARO, Carlos, La Constitución y Libertades de Aragón y el Justicia Mayor, Reus, Madrid, 1926, p. 191 y ss. Entre los artículos básicos inherentes a la formación del reino de Sobrarbe, según el texto de Blancas, el art. III prescribe: "No podrá el Rey juzgar por si causa alguna sino con intervención del Consejo de sus súbditos" -cfr. op. cit., p. 192-; (este libro, que se encuentra agotado, llegó a mis manos por gentileza de un librero de Marcial Pons). Llama la atención que en España, con posterioridad a la Constitución de 1978, los textos constitucionales no hayan recogido este antiguo principio en que se funda el sistema judicialista español, base de los hispano-americanos, lúcidamente desarrollado en el Discurso Preliminar de Arguelles.

A \& C R. de Dir. Administrativo \& Constitucional, Belo Horizonte, ano 8, n. 31, p. 69-89, jan./mar. 2008 
que consagra la prohibición de ejercer funciones judiciales en cabeza del Poder Ejecutivo fue adoptado o bien, se encuentra en vigencia en el actual derecho positivo constitucional de dichos países.

Esta situación acontece, de manera expresa o implícita, en los ordenamientos constitucionales de diversas repúblicas hispanoamericanas (aparte de Chile y Argentina) como Perú, ${ }^{48}$ Paraguay, ${ }^{49}$ Nicaragua, ${ }^{50}$ Panamá, ${ }^{51}$ Guatemala,${ }^{52}$ Costa Rica, ${ }^{53}$ e incluso se refleja en otros países tal el caso de México, ${ }^{54}$ Brasil ${ }^{55}$ y Venezuela,${ }^{56}$ donde el proceso de evolución constitucional las llevó a apartarse del modelo norteamericano, al menos en este punto que hace a la irreductibilidad del principio judicialista puro.

En la misma línea que la Constitución Argentina y los precedentes constitucionales transandinos, la Constitución de Chile actualmente en vigencia (sancionada en 1980) ha continuado la tradición histórica del

${ }^{46}$ Cfr. Constitución Política de la Monarquía Española promulgada en Cádiz a 19 de mayo de 1812, con prólogo de Eduardo GARCÍA DE ENTERRÍA, Civitas, Madrid, 1999, p. 64.

47 Cuya primera parte prescribe: "Ningún habitante de la Nación puede ser penado sin juicio previo fundado en ley anterior al hecho del proceso, ni juzgado por comisiones especiales, o sacado de los jueces designados por la ley antes del hecho de la causa...".

${ }^{48}$ Constitución de Perú. Art. 139: "Son principios y derechos de la función jurisdiccional: 1. La unidad y exclusividad de la función jurisdiccional. No existe ni puede establecerse jurisdicción alguna independiente, con excepción de la militar y la arbitral. No hay proceso judicial por comisión o delegación. 2. La independencia en el ejercicio de la función jurisdiccional. Ninguna autoridad puede avocarse a causas pendientes ante el órgano jurisdiccional ni interferir en el ejercicio de sus funciones. Tampoco puede dejar sin efecto resoluciones que han pasado en autoridad de cosa juzgada, ni cortar procedimientos en trámite, ni modificar sentencias ni retardar su ejecución. Estas disposiciones no afectan el derecho de gracia ni la facultad de investigación del Congreso, cuyo ejercicio no debe, sin embargo, interferir en el procedimiento jurisdiccional ni surte efecto jurisdiccional alguno...".

49 Constitución de Paraguay. Art. 248. "De la independencia del Poder Judicial: Queda garantizada la independencia del Poder Judicial. Sólo éste puede conocer y decidir en actos de carácter contencioso. En ningún caso los miembros de los otros poderes, ni otros funcionarios, podrán arrogarse atribuciones judiciales que no estén expresamente establecidas en esta Constitución, ni revivir procesos fenecidos, ni paralizar los existentes, ni intervenir de cualquier modo en los juicios. Actos de esta naturaleza conllevan nulidad insanable. Todo ello sin perjuicio de las decisiones arbitrales en el ámbito del derecho privado, con las modalidades que la ley determine para asegurar el derecho de defensa y las soluciones equitativas. Los que atentasen contra la independencia del Poder Judicial y la de sus magistrados, quedarán inhabilitados para ejercer toda función pública por cinco años consecutivos, además de las penas que fije la ley".

50 Constitución de Nicaragua. Art. 158: "La justicia emana del pueblo y será impartida en su nombre y delegación por el Poder Judicial, integrado por los Tribunales de Justicia que establezca la ley. Art. 159: "Los tribunales de justicia forman un sistema unitario, cuyo órgano superior es la Corte Suprema de Justicia... Las facultades jurisdiccionales de juzgar y ejecutar lo juzgado corresponden exclusivamente al Poder Judicial. Los tribunales militares sólo conocerán las faltas y delitos estrictamente militares, sin perjuicio de las instancias y recursos ante la Corte Suprema de Justicia".

51 Constitución de Panamá. Art. 199: "El Órgano Judicial esta constituido por la Corte Suprema de Justicia, los Tribunales y los Juzgados que la Ley establezca". Art. 203: "La Corte Suprema de Justicia tendrá, entre sus atribuciones constitucionales y legales, las siguientes: 1. La guarda de la integridad de la Constitución para lo cual la Corte en pleno conocerá y decidirá, con audiencia del Procurador General de la Nación o del Procurador de la Administración, sobre la inconstitucionalidad de la Leyes, decretos, acuerdos, resoluciones y demás actos que por razones de fondo o de forma impugne ante ella cualquier persona. Cuando en un proceso público el funcionario encargado de impartir justicia advirtiere o se lo advirtiere alguna de las partes que la disposición legal o reglamentaria aplicable al caso es inconstitucional, someterá la cuestión al conocimiento del pleno de la Corte, salvo que la disposición haya sido objeto de pronunciamiento por parte de ésta, y continuará el 


\section{principio judicialista puro hispánico en los siguientes términos:}

Art. 73: La facultad de conocer de las causas civiles y criminales, de resolverlas y de hacer ejecutar lo juzgado, pertenece exclusivamente a los tribunales establecidos por la ley. Ni el Presidente de la República ni el Congreso pueden, en caso alguno, ejercer funciones judiciales, avocarse causas pendientes, revisar los fundamentos o contenidos de sus resoluciones o hacer revivir procesos fenecidos.

\section{Principales diferenci as e n - tre el sistema judicialista de iberoamérica y el modelo norteamericano}

Un error inicial de interpretación sobre el alcance de las fuentes constitucionales y sus bases históricas condujo a un sector de la doctrina a sostener que el sistema judicialista de algunos países iberoamericanos, como Argentina, ${ }^{57}$ ha adoptado íntegramente el modelo norteamericano. Esta postura, parcialmente cierta en punto a determinados aspectos de

curso del negocio hasta colocarlo en estado de decidir. Las partes sólo podrán formular tales advertencias una vez por instancia. 2. La jurisdicción contencioso-administrativa respecto de los actos, omisiones, prestación defectuosa o deficiente de los servicios públicos, resoluciones, órdenes o disposiciones que ejecuten, adopten, expidan o que incurran en el ejercicio de sus funciones o pretextando ejercerlas, los funcionarios públicos y autoridades nacionales, provinciales, municipales y de las entidades públicas autónomas o semiautónomas. A tal fin, la Corte Suprema de Justicia con audiencia del Procurador de la Administración, podrá anular los actos acusados de ilegalidad; restablecer el derecho particular violado; estatuir nuevas disposiciones en reemplazo de las impugnadas y pronunciarse prejudicialmente acerca del sentido y alcance de un acto administrativo o de su valor legal. Podrán acogerse a la jurisdicción contencioso-administrativa las personas afectadas por el acto, resolución, orden o disposición de que se trate; y, en ejercicio de la acción pública, cualquier persona natural o jurídica domiciliada en el país. Las decisiones de la Corte en el ejercicio de las atribuciones señaladas en este artículo son finales, definitivas, obligatorias y deben publicarse en la Gaceta Oficial".

52 Constitución de Guatemala. Art. 203: "Independencia del Organismo Judicial y potestad de juzgar. La justicia se imparte de conformidad con la Constitución y las leyes de la República. Corresponde a los tribunales de justicia la potestad de juzgar y promover la ejecución de los juzgados. Los otros organismos del Estado deberán prestar a los tribunales el auxilio que requieran para el cumplimiento de sus resoluciones. Los magistrados y jueces son independientes en el ejercicio de sus funciones y únicamente están sujetos a la Constitución de la República y a las leyes. A quienes atentaren contra la independencia del Organismo Judicial, además de imponérseles las penas fijadas por el Código Penal, se les inhabilitará para ejercer cualquier cargo público. La función jurisdiccional se ejerce, con exclusividad absoluta, por la Corte Suprema de Justicia y por los demás tribunales que la ley establezca. Ninguna otra autoridad podrá intervenir en la administración de justicia".

53 Constitución de Costa Rica. Art. 155: "Ningún tribunal puede avocar el conocimiento de causas pendientes ante otro. Únicamente los tribunales del Poder Judicial podrán solicitar los expedientes ad afféctum videndi".

54 Constitución de México. Art. 49: "El Supremo Poder de la Federación se divide, para su ejercicio, en Legislativo, Ejecutivo y Judicial. No podrán reunirse dos o más de estos Poderes en una sola persona o corporación, ni depositarse el Legislativo en un individuo, salvo el caso de facultades extraordinarias al Ejecutivo de la Unión, conforme a lo dispuesto en el artículo 29. En ningún otro caso, salvo lo dispuesto en el segundo párrafo del artículo 131, se otorgarán facultades extraordinarias para legislar". Art. 94: "Se deposita el ejercicio del Poder Judicial de la Federación en una Suprema Corte de Justicia, en un Tribunal Electoral, en Tribunales Colegiados y Unitarios de Circuito y en Juzgados de Distrito. La administración, vigilancia y disciplina del Poder Judicial de la Federación, con excepción de la Suprema Corte de Justicia de la Nación, estarán a cargo del Consejo de la Judicatura Federal en los términos que, conforme a las bases que señala esta Constitución, establezcan las leyes".

55 Arts. 92 y 102.l.a) de la Constitución de Brasil.

56 Art. 259 de la Constitución de Venezuela. 
la organización del poder judicial, no tiene en cuenta que la interdicción del ejercicio de funciones judiciales que se impone al Ejecutivo ${ }^{58}$ constituye la pieza básica en que se apoya la estructura del sistema judicialista argentino y de otros países iberoamericanos que adoptaron la fórmula prescripta en la Constitución de Cádiz de 1812, ${ }^{59}$ inexistente en el modelo norteamericano. En cierto modo, la prohibición constitucional configura el principio que marca un judicialismo puro, ${ }^{60}$ consagrando un límite prácticamente absoluto o al menos sumamente acotado al ejercicio de funciones jurisdiccionales por parte de entes o tribunales administrativos, difiriendo en esto claramente del modelo norteamericano que no contiene una norma semejante. ${ }^{61}$

La cuestión ha dejado de tener un mero interés histórico (comúnmente devaluado) para asumir una enorme trascendencia jurisprudencial y doctrinaria, a propósito de un reciente fallo de la Corte Suprema argentina (caso “Ángel Estrada”) ${ }^{62}$, que ha venido a confirmar la fuerza jurígena del principio y su fuente, reiterando la tradicional concepción de que los entes administrativos sólo excepcionalmente, y siempre que se cumplan determinados requisitos, pueden ejercer funciones jurisdiccionales (cuando ello se justifique en razones de especialidad, nunca como cláusula general) a condición de que exista un control judicial suficiente, con amplitud de debate y prueba. ${ }^{63}$

De ahí que las diferencias más notables entre algunos sistemas hispanoamericanos de control judicial de la actividad administrativa, (como el argentino) y el modelo norteamericano radiquen, precisamente, en el reconocimiento generalizado en este último, de una llamada jurisdicción administrativa primaria que actúa, tanto en el orden positivo como en el

\footnotetext{
57 Entre otros: MAIRAL, Héctor A., Control judicial de la Administración Pública, To I, Depalma, Buenos Aires, 1984 , p. 95

58 Art. 109 (ex 95) de la Constitución Nacional de Argentina.

59 Art. 243 de la Constitución de Cádiz.

60 Así lo ha destacado la doctrina española -que lo denomina clásico o puro-; vid entre otros: NIETO, Alejandro, "Los orígenes de lo contencioso administrativo en España", Revista de Administración Pública, n. 50, Instituto de Estudios Políticos, Madrid, 1966, p. 28; FERNÁNDEZ TORRES, Juan Ramón, La formación histórica..., cit., ps. 96-97.

${ }^{61}$ Como lo ha destacado Tawil, uno de los pocos publicistas que ha advertido la trascendencia del principio en el sistema judicialista. En cambio, si bien la mayoría lo mencionan prácticamente no le dan cabida o sentido principal dentro del sistema constitucional; véase: TAWIL, Guido S., Administración y justicia. Alcance del control judicial de la actividad administrativa, To I, Depalma, Buenos Aires, 1993, p. 117 y ss.

62 Corte Suprema de Justicia de la Nación, 05/04/2005, "Angel Estrada y Cía. SA c. Secretaría de Energía y Puertos".
} 
de la realidad, como una primera instancia del proceso de revisión de la legitimidad administrativa.

No obstante, la configuración de dicha jurisdicción administrativa primaria no implica asimilar el sistema norteamericano (que sigue siendo judicialista o mejor dicho mixto) al modelo francés, basado en tribunales administrativos para juzgar a la Administración, pues al menos en teoría, el poder judicial (en el esquema estadounidense) es quien conserva la facultad final de juzgar.

Sin embargo, el funcionamiento del modelo norteamericano ha evolucionado hacia un sistema mixto básicamente por tres razones fundamentales: a) el reconocimiento generalizado de la jurisdicción administrativa prima para las causas del derecho estatutario (statutory law) que son las equivalentes a nuestro derecho administrativo positivo; b) la limitación de la revisión judicial, ${ }^{64}$ en principio, a los aspectos de fondo o de derecho o por la llamada doctrina de la deferencia; ${ }^{65}$ y c) la exclusión de la revisión judicial por la ley o el marco regulatorio específico e incluso, por la actuación discrecional de la agencia. ${ }^{66}$

En cambio, en los sistemas judicialistas puros, como el argentino, basados en la cláusula constitucional que prohíbe al Poder Ejecutivo el ejercicio de funciones judiciales, el reconocimiento de funciones de naturaleza jurisdiccional, (i) no puede hacerse por vía de una cláusula generalizada, (ii) requiere de una ley basada en un fundamento de especiali-

\footnotetext{
${ }^{63}$ Doctrina de la Corte Suprema que surge del leading case "Fernández Arias c/ Poggio s/ sucesión", Fallos, 247:646 (1960)

64 Cfr. GARCÍA DE ENTERRÍA, Eduardo, Democracia, jueces y control de la Administración, Civitas, Madrid, 1995, p. 172 y ss. En este trabajo, realmente modélico, García de Enterría apunta: "Recordemos que en cuanto a la apreciación de los hechos la tradición americana es que la judicial review sobre la Administración se configure como un appeal, apelación en el sentido angloamericano, que remite la apreciación de hechos al juez de primera instancia y se limita al control del Derecho (como la casación según nuestro sistema y como el arcaico sistema contencioso europeo del siglo XIX -y español, hasta la Ley de la Jurisdicción de 1956-, según el sistema del "Ministro Juez"). Este criterio está robustecido de hecho por la circunstancia de que las Leyes reguladoras de cada materia (no hay una regulación general del recurso contencioso-administrativo uniforme en una normativa especial y común, como ocurre en Europa) atribuyen normalmente la judicial review inicial a las Courts of Appeal federales, que no hacen más que repetir en esta review sus hábitos enjuiciadores ordinarios como jueces de apelación, partiendo, pues, de la apreciación de hechos realizada por la Administración. Aunque hoy ese dogma tradicional no se mantiene tan rígidamente, sigue preponderando. Si se parte, pues, de un crédito casi en blanco a la Administración en cuanto a la apreciación de los hechos, o al menos del criterio de que la crítica de esa apreciación se limita a los elementos que puedan resultar del propio expediente, se comprende que esa "deferencia", enfáticamente proclamada desde Chevron, de los Tribunales también a las interpretaciones jurídicas que pueda hacer la Administración, viene a arruinar, quizás en su parte substancial, la efectividad del control judicial de la Administración". (op. cit., ps. 173-174).

65 Véase también: BIANCHI, Alberto B., La regulación económica, To I, Abaco, Buenos Aires, 2001, p. 287 y ss., y nuestro Derecho Adminsitrativo, To II, $7^{\circ}$ ed. act., Lexis Nexis Abeledo Perrot, Buenos Aires, 2002, ps. 414-416.
} 
dad y razonabilidad que la justifique, (iii) como también que el órgano o ente que ejerza dichas funciones sea independiente del Ejecutivo, y (iv) exigiéndose, en cualquier caso, que quede siempre abierta la posibilidad de llevar a cabo un control judicial pleno y suficiente, con amplitud de debate y prueba. ${ }^{67}$

\section{A modo de conclusión: el hilo conductor del sistema judicialista en el modelo norteamericano}

Aun cuando esta cuestión demanda un estudio más exhaustivo, la investigación preliminar que efectuamos precedentemente arroja algunas conclusiones que hace unos años, para la mayoría de los juristas, habrían parecido heréticas, no obstante que desde diferentes atalayas y épocas históricas se propició la correcta interpretación ${ }^{68}$ acerca de las raíces hispánicas de las principales concepciones del derecho público moderno, particularmente el derecho constitucional de los diferentes países de América.

En tal sentido, el hilo conductor del sistema es la defensa de la libertad, a través del sistema democrático instituido sobre la base de que la causa directa del poder no es de origen divino sino que se encuentra en el consentimiento del pueblo, al propio tiempo que instrumenta una versión americana de la separación de poderes, caracterizada por la independencia del poder judicial. Se configura algo así como la antípoda del absolutismo que predicaron tanto Jacobo I en Inglaterra como los borbones en Francia y más tarde en España.

De ese modo, el sistema judicialista se convierte en la clave del equilibrio, a diferencia de las concepciones europeas, sobre todo, las vigentes en el continente, que potenciaron, en su esquema constitucional, el predominio del Legislativo sobre los demás poderes del Estado, siguiendo la versión francesa de matriz roussoniana.

La justicia cumple entonces el papel de árbitro independiente tanto en los conflictos entre particulares como en los que se suscitan entre éstos y el Estado para limitar los demás poderes, garantizando las libertades y demás derechos fundamentales de naturaleza individual.

\footnotetext{
665 U.S.C. $\$ 701$

67 Corte Suprema de Justicia de la Nación, 05/04/2005, "Angel Estrada y Cía. SA c. Secretaría de Energía y Puertos", que, en este punto, ha seguido nuestra tesis. En una postura que nos parece más estricta se ha dicho que la administración no debería ejercer función jurisdiccional alguna: GELLI, María Angélica, Constitución de la Nación Argentina. Comentada y concordada, La Ley, Buenos Aires, 2003, p. 754.

68 Desde la obra de SUÁREZ, Defensio Fidei, hasta el Discurso Preliminar de Agustín ARGUELLES, que acompañó la publicación de la Constitución de Cádiz de 1812, para citar dos obras ejemplares.
} 
El hecho de que en la práctica subsistan, en América, sistemas judicialistas puros como el argentino y el brasileño (en los que prevalece el control judicial pleno) con versiones como la norteamericana que ha ido instrumentando, cada vez con mayor extensión, un sistema de tribunales administrativos descentralizados (y por tanto diverso al modelo francés del Consejo de Estado) junto a la generalización de una llamada justicia administrativa primaria y a la

limitación de la revisión de la actividad administrativa no es óbice para negar la raíz similar en que se apoyan ambos sistemas que han sido, en realidad, aplicaciones de la filosofía política de la neoescolástica y de las concepciones vigentes en el antiguo derecho español.

Esta sola conclusión va mucho más allá del origen común habida cuenta que viene a justificar, con las debidas cautelas, la razón de ser del sistema judicialista y de las posibilidades aplicativas de las soluciones que brinda cada sistema en el otro. La paradoja es que en ese intercambio suele prevalecer el país con mayor peso e influencia política, aun cuando el nivel de su cultura jurídica sea menor.

Como puede advertirse, la riqueza del antiguo derecho español es inagotable y merece la realización de investigaciones mayores y profundas. La que hemos hecho sea, quizás, contando con la benevolencia de quienes lo juzguen, es tan solo un ensayo que intenta una primera aproximación a un tema clásico, pero siempre vigente, con la idea de suscitar nuevas reflexiones alrededor de un punto de partida distinto, cuya proyección, en el derecho público moderno, sobre todo en el hispanoamericano, no parece haberse encarado en forma sistemática con la profundidad que merece, particularmente en lo que atañe al sistema judicialista que nos rige.

De ese modo, sin desdeñar los avances logrados por la dogmática moderna, el mayor desafío habrá que ponerlo tanto en desentrañar las fuentes de las concepciones constitucionales americanas como en armonizar su interpretación a la luz de los principios, usos y costumbres vigentes confrontándolos con los principios tradicionales de nuestro derecho público de origen hispánico, donde se ubican las raíces de muchas de las libertades que actualmente gozamos los ciudadanos de Iberoamérica.

Informação bibliográfica deste texto, conforme a NBR 6023:2002 da Associação Brasileira de Normas Técnicas (ABNT):

CASSAGNE, Juan Carlos. El Sistema Judicialista Americano: Sus Raíces Hispánicas. A\&C Revista de Direito Administrativo e Constitucional, Belo Horizonte, ano 8, n. 31,

A \& C R. de Dir. Administrativo \& Constitucional, Belo Horizonte, ano 8, n. 31, p. 69-89, jan./mar. 2008 
p. 69-89, jan./mar. 2008.

A \& C R. de Dir. Administrativo \& Constitucional, Belo Horizonte, ano 8, n. 31, p. 69-89, jan./mar. 